\title{
UMA NOVA ESPÉCIE DE SCAPHOIDULA OSBORN (HOMOPTERA, CICADELLIDAE, DELTOCEPHALINAE) ${ }^{1}$
}

\author{
Keti Maria Rocha Zanol ${ }^{2}$
}

\begin{abstract}
A NEW SPECIES OF SCAPHOIDULA OSBORn (HOMOPTERA: CiCADELLIDAE, DELTOCEPHALINAE). Scaphoidula webbi sp.n., from Brazil, is described. KEY WORDS. Homoptera, Cicadellidae, Deltocephalinae, Scaphoidula
\end{abstract}

$\mathrm{O}$ material estudado pertence às seguintes Instituições: Instituto Nacional de Pesquisas da Amazônia, Manaus (INPA) e Coleção de Entomologia Pe J.S. Moure, Departamento de Zoologia, Universidade Federal do Paraná, Curitiba (DZUP).

\section{Scaphoidula webbi sp.n. \\ Figs 1-4}

Holótipo fêmea. Cabeça, em vista dorsal, mais longa medianamente e de largura maior que o pronoto. Ocelos situados na margem anterior, perto dos olhos, visíveis de cima. Área ocelo-ocular menor que o diâmetro dos ocelos. Sutura coronal atingindo a metade do comprimento da coroa. Coloração geral marfim, com duas faixas transversas, acompanhando a curvatura da cabeça, uma sobre o disco, marrom-avermelhada e outra, mais estreita, entre os ocelos, marrom-escura. Face mais ou menos achatada e ampla, de coloração geral marfim; duas faixas transversas paralelas, marrom-escuras; uma situada logo abaixo dos ocelos e a outra acima dos alvéolos antenais; uma faixa transversa, de cada lado, abaixo dos olhos, estendida desde a sutura frontoclipeal até à borda, marrom-escura. Frontoclípeo levemente túmido. Anteclípeo com ápice alargado. Genas com bordos sinuosos.

Pronoto de superfície lisa, de coloração marfim com duas faixas transver-sas, paralelas às da cabeça, marrom-avermelhadas: a anterior mais curta, atingindo a metade dos olhos e, a posterior, sobre o disco, com os bordos voltados para baixo antes de atingir as margens laterais. Escutelo marfim com duas faixas transversas marrom-avermelhadas: a anterior na base, junto ao pronoto e a posterior, logo abaixo da sutura. Tégminas com duas células anteapicais, semitransparentes, com linhas longitudinais marrom-escuras ao longo da veia Média, sutura claval e margem anal até a altura do apêndice; mais três obliquas entre aquelas ao longo da veia Média e a sutura claval, alcançando a célula braquial e, também, outras menores junto as

1) Contribuição número 969 do Departamento de Zoologia, Universidade Federal do Paraná.

2) Departamento de Zoologia, Universidade Federal do Paraná. Caixa Postal 19020, 81531-990 Curitiba, Paraná, Brasil. Bolsista do CNPq. 
células apicais; ápice marrom. Venação distinta de cor marfim em algumas partes. Apêndice desenvolvido. Espinulação das tíbias anteriores 1+4 e dos fêmures posteriores $2+2+1$.

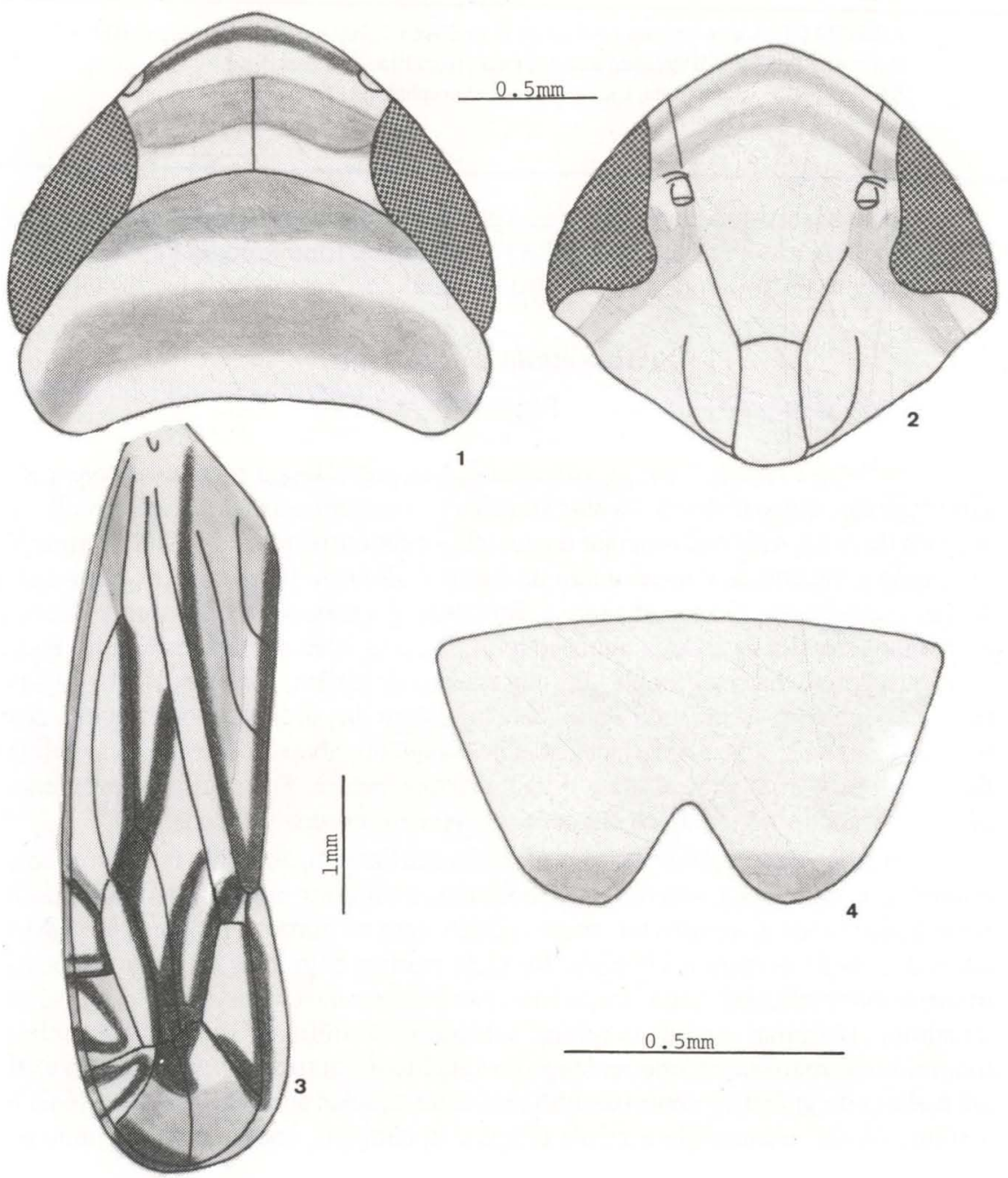

Figs 1-4. Scaphoidula webbi sp.n.. (1) Cabeça e pronoto, dorsal; (2) face; (3) tégmina; (4) VII esternito. 
Genitália. Fêmea - sétimo esternito mais largo do que longo; margem posterior arredondada com uma fenda mediana, em forma de V; margens de cada lado da fenda marrons.

Macho. Desconhecido.

Comprimento total $6,60 \mathrm{~mm}$.

Material examinado. Holótipo fêmea. BRASIL, Roraima: Ilha de Maracá (Rio Uraricoara), 21-30.XI.1987, J.A. Rafael e equipe leg. (INPA). Parátipos. Duas fêmeas da mesma localidade e data (DZUP, INPA).

Comentários. Esta espécie é semelhante a $S$. mourei Zanol mas a margem posterior do sétimo esternito é amplamente arredondada; a fenda mediana é maior e mais larga.

Etimologia. O nome da espécie é em homenagem ao Dr. M.D. Webb do The Natural History Museum, Londres.

\section{REFERÊNCIAS BIBLIOGRÁFICAS}

LINNAVUORI, R. 1959. Revision of the Neotropical Deltocephalinae and some related subfamilies (Homoptera). Ann. zool. Soc. Bot. fennicae Vanamo 20 (1): $1-370$.

Menezes, M. DE. 1973. Notas sobre Deltocephalinae da região Neotropical (Homoptera: Cicadellidae). Revta bras. Ent. 17 (20): 131-136.

OMAN, P.W. 1937. The leafhoppers of the genus Scaphoidula (Homoptera: Cicadellidae). Rev. Ent. 7 (1): 92-96.

OsBorn, H. 1923. II. Neotropical Homoptera of the Carnegie Museum. Part 2.

Records and description of five new genera and sixty-five new species of the subfamily Jassinae. Ann. Carneg. Mus. 15 (1): 27-79.

ZANOL, K.M.R. 1988. As espécies do gênero Scaphoidula, Osborn, 1923 (Homoptera: Cicadellidae). Revta bras. Ent. 32 (3/4): 416-422.

. 1989. Nova espécie de Scaphoidula Osborn, 1923 (Homoptera: Cicadelliddae). An. Soc. Ent. Brasil 18 (2): 371-372.

Recebido em 26.IX.1996; aceito em 09.IV.1997 